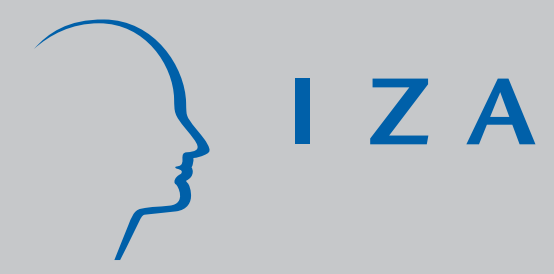

IZA DP No. 1783

Executive Compensation, Firm Performance, and Chaebols in Korea: Evidence from New Panel Data

Takao Kato

Woochan Kim

Ju Ho Lee

September 2005 


\title{
Executive Compensation, Firm Performance, and Chaebols in Korea: Evidence from New Panel Data
}

\author{
Takao Kato \\ Colgate University, Columbia University \\ and IZA Bonn \\ Woochan Kim \\ KDI School of Public Policy and Management \\ Ju Ho Lee \\ KDI School of Public Policy and Management
}

Discussion Paper No. 1783

September 2005

\author{
IZA \\ P.O. Box 7240 \\ 53072 Bonn \\ Germany \\ Phone: +49-228-3894-0 \\ Fax: +49-228-3894-180 \\ Email: iza@iza.org
}

\begin{abstract}
Any opinions expressed here are those of the author(s) and not those of the institute. Research disseminated by IZA may include views on policy, but the institute itself takes no institutional policy positions.
\end{abstract}

The Institute for the Study of Labor (IZA) in Bonn is a local and virtual international research center and a place of communication between science, politics and business. IZA is an independent nonprofit company supported by Deutsche Post World Net. The center is associated with the University of Bonn and offers a stimulating research environment through its research networks, research support, and visitors and doctoral programs. IZA engages in (i) original and internationally competitive research in all fields of labor economics, (ii) development of policy concepts, and (iii) dissemination of research results and concepts to the interested public.

IZA Discussion Papers often represent preliminary work and are circulated to encourage discussion. Citation of such a paper should account for its provisional character. A revised version may be available directly from the author. 
IZA Discussion Paper No. 1783

September 2005

\section{ABSTRACT}

\section{Executive Compensation, Firm Performance, and Chaebols in Korea: Evidence from New Panel Data}

This paper provides the first rigorous econometric estimates on the pay-performance relations for executives of Korean firms with and without Chaebol affiliation. To do so, we have assembled for the first time panel data (that provide information not only on executive compensation and firm performance but also on Chaebol affiliation) for 246 firms that were included in KOSPI200 for at least two consecutive years from 1998 to 2001 . Contrary to a popular belief that Korean corporate governance and the structure of Korean executive compensation is considerably different from elsewhere in the West, we find that cash compensation of Korean executives is statistically significantly related to stock market performance and that the magnitude of the sensitivity of pay to stock market performance is comparable to the U.S. and Japan. Perhaps even more importantly, further analysis reveals for the first time that such overall significant executive pay-performance link is driven by nonChaebol firms and that no such link exists for Chaebol firms. The evidence is consistent with the recent literature on the nature of Chaebols in Korea and the current corporate governance reform efforts in Korea that are aimed mostly at Chaebol firms.

JEL Classification: M52, M12, G30, G15, J33, O53

Keywords: executive compensation, firm performance, corporate governance, Korea, Chaebols

Corresponding author:

Takao Kato

Department of Economics

Colgate University

13 Oak Drive

Hamilton, NY 13346

USA

Email: tkato@mail.colgate.edu 


\section{EXECUTIVE COMPENSATION, FIRM PERFORMANCE, AND CHAEBOLS IN KOREA: Evidence from New Panel Data}

\section{$\underline{\text { I. Introduction }}$}

While there has been an explosion in research on executive compensation in U.S. firms in recent years, ${ }^{1}$ systematic research on executive compensation outside of the U.S., in particular in Asia, is still relatively scarce mostly due to the limited data availability. Specifically, unlike in the U.S., Asian firms have not been required to disclose information on compensation for any individual executives, and hence compensation data on individual executives of Asian corporations have not been available for researchers.

Though not required to report salary and bonus of CEOs, however, Japanese corporations are required to report total salary and bonus earned by all directors, and such aggregate executive compensation data are readily available annually over an extended period of time. A few studies have exploited this aggregate data set of Japanese publicly traded firms and have examined the determinants of executive compensation in Japan. ${ }^{2}$

Except for Japan, however, systematic econometric estimates on the pay-performance relations for executives of Asian firms are virtually non-existent. ${ }^{3}$ This paper fills an important gap in the literature by providing the first rigorous econometric evidence on the pay-performance relations of executives of Korean firms with and without Chaebol affliction, using new panel data on executive compensation of over 200 leading corporations listed in KSE (Korea Stock

${ }^{1}$ A number of excellent surveys on this literature are available. See, for example, Murphy (1999) for the mostly empirical literature and Gibbons (1997) for the largely theoretical literature. For an authoritative survey of earlier work, see Rosen (1990) who concludes his survey by urging scholars to broaden their inquiry beyond the U.S. to other countries.

${ }^{2}$ See, for instance, Kaplan (1994), Xu (1997), Ang and Constand (1997), Joh (1999), Kubo (2001) and Kato and Kubo (2003). For studies using an alternative income tax return data set in Japan, see Kato and Rockel (1992) and Kato (1997).

${ }^{3}$ In the English-language literature, we are aware of only two studies on China. Groves and et.al. (1995) examine the pay-performance relations for managers in China's state-owned firms in the 1980s and Kato and Long (2004) study the pay-performance relations for top management in China’s listed firms in recent years. 
Exchange) over the period of 1998-2001. ${ }^{4}$ In so doing, the paper contributes to one of the most important recent public-policy debates in Asia, or corporate governance reform. ${ }^{5}$

The proponents of such reform argue that Asian corporate governance is not sufficiently oriented towards shareholders and recommend changes that will bring Asian corporate governance more in line with the Anglo-American model. In fact, some of their recommendations have been already implemented. ${ }^{6}$ Unfortunately, however, existing evidence on the nature of managerial incentives in Asian firms is limited and mixed. The present study provides the first systematic evidence on the pay-performance relations for executives of Korean firms with and without Chaebol affiliation and thus offers important information currently missing in the debate.

Specifically, contrary to a popular belief that Korean corporate governance and the structure of Korean executive compensation is vastly different from elsewhere in the West, we find that cash compensation of Korean executives is statistically significantly related to stock market performance and that the magnitude of the sensitivity of pay to stock market performance is comparable to the U.S. and Japan. Moreover, alternative performance measures (such as accounting performance and sales) turn out to play a less important role in the determination of Korean executive compensation. Finally, we find that non-Chaebol firms appear to structure their executive compensation so as to reward their executives for improving shareholder value more so than Chaebol firms. The evidence is consistent with the recent literature on the nature of Chaebols in Korea and the current corporate governance reform efforts in Korea that are

${ }^{4}$ We are aware of several Korean-language papers on the subject, such as Hwang (1995), Kim, Chung and Ji (1999), and Shin, Lee and Chang (2003). On our reading of the literature, however, our paper is the first English-language paper on Korean executive compensation and definitely the first paper (including both Englishand Korean-language papers) which studies the differences in pay-performance relations for Korean executives between Chaebol and non-Chaebol firms.

${ }^{5}$ See, for example, Nam (2002), Ahmadjian (2001), Black, Jang and Kim (2003) and Choe and Lee (2003) for the current debate on corporate governance reform in Asia.

${ }^{6}$ See, for example, World Bank (2003). 
targeted largely at Chaebol firms.

In the next section we begin with background information on Korean executive compensation and corporate governance with particular emphasis on Chaebols, and then introduce the data and describe our empirical strategy in Section III. The results are presented in Section IV, followed by a concluding section.

\section{Corporate Governance and Chaebols in Korea}

Since the financial crisis of 1997/98, many scholars started to show interest in large business groups of East Asia. They particularly showed interest in the separation of ownership and control rights resulting from stock pyramids and cross-ownership of equity dominant in Asian business groups. For example, Claessens, Djankov, and Lang (2000) document the separation of ownership and control in nine East Asian countries and show that such separation is most pronounced among family-controlled firms. ${ }^{7} \quad$ In their study of eight East Asian countries, Claessens, Djankov, Fan, and Lang (2002) show that firm value falls when the control rights of the largest shareholder exceed its cash-flow ownership, consistent with the an entrenchment effect. $^{8} \quad$ Another line of research investigates the performance of East Asian firms during the crisis. For example, Mitton (2002) documents that in five crisis-hit countries, significantly better stock price performance is associated with firms that had higher quality of corporate governance. ${ }^{9}$ In their study of eight East Asian countries, Lemmon and Lins (2003) show stock returns of firms in which managers have high levels of control rights, but have Thailand.

7 They study Hong Kong, Indonesia, Japan, Korea, Malaysia, the Philippines, Singapore, Taiwan, and

8 They study Hong Kong, Indonesia, Korea, Malaysia, the Philippines, Singapore, Taiwan, and Thailand.

9 They study Korea, Malaysia, the Philippines, and Thailand. 
separated their control and cash flow ownership, are significantly lower than those of other firms during the crisis period. ${ }^{10}$

There are also a number of Korea specific papers studying the behavior of chaebols, family-controlled large business groups in Korea. Form example, Joh (2003) shows that firms affiliated to a chaebol group experienced lower operational profits during the pre-crisis period. ${ }^{11}$ Baek, Kang, and Park (2003) and Kim and Lee (2003) show that this was also the case for stock price performance during the crisis period. ${ }^{12}$ Campbell and Keys (2003) also show that firms affiliated with the top five chaebols exhibit significantly lower performance and significantly higher sales growth relative to others during the 1993-1999 period. Jung and Kwon (2002) look at earnings informativeness instead of firm performance. They show that in chaebol firms, as opposed to non-chaebol firms, no significant relationship is found between the largest shareholder's holdings and earnings informativeness. ${ }^{13}$

There are three additional papers more closely related to our project. Bae, Kang, and Kim (2002) show that when a chaebol-affiliated firm makes an acquisition, its stock price on average falls, but the market value of other firms in the group rises. ${ }^{14}$ This evidence tells that while minority shareholders of a chaebol-affiliated firm making an acquisition loses, the controlling shareholder of that firm on average benefits. This result is relevant to our research because it shows that chaebol-affiliated firms are not independently run, but operated to

10 They study Hong Kong, Indonesia, Korea, Malaysia, the Philippines, Singapore, Taiwan, and Thailand

11 She uses top-70 chaebols. She constructs this list by adding 40 additional chaebols to the top-30 chaebols classified by the Korea Fair Trade Commission (KFTC). KFTC announces the list for its own purpose to restrict equity investments, mutual debt guarantees, and mutual shareholdings among group-affiliated firms. KFTC defines a chaebol as "a group of companies of which more than $30 \%$ of its shares are owned by the group's controlling shareholder and its affiliated companies.” Each year, the KFTC ranks business groups according to the size of their total assets and identifies the 30 largest business groups.

12 Both studies use top-30 chaebols as their base, but conduct robustness checks with top-50 and top-70 chaebols.

13 They use top-30 chaebols.

14 They use top-30 chaebols. 
maximize the interest of the overall group or the controlling family's interest. This is more evident in internal capital market studies. For example, Shin and Park (1999) show that investment-cash flow sensitivity is low and insignificant for chaebol firms but is high and significant for non-chaebol firms. ${ }^{15}$ They also show that a chaebol firm's investment is significantly affected by the cash flow of other firms within the same chaebol group even though they are independent legal entities.

Such evidence suggests that group’s interest might be considered in the top executive replacement decisions too. That is, if group chairman or controlling shareholder mandates top executives to pursue the interest of chaebol as a whole, executive turnover might be insensitive to individual firm-level performance. Campbell and Keys (2003) shows exactly such evidence. Using data between 1993 and 1999, they show that top executive turnover in firms affiliated to top five chaebols is unrelated to firm-level performance. On the other hand, they show that managers of firms unrelated to the top five chaebols are significantly more likely lose their job when performance deteriorates.

In this paper, we intend to uncover similar evidence in the determination of executive compensation. That is, if top executives of chaebol are mandated to pursue the interests of the overall group, and not the shareholders' interest of the firm he or she works for, their cash compensation would be less sensitive to firm-level performance compared to those firms unaffiliated to any chaebol group.

Institutional information on who sets executive compensation and how it is set is very limited in Korea. It is very rare for companies to have compensation committees and even for firms that do have such a committee, they do not disclose any of their activity. One exception is the SOEs that are subject to the "State Owned Enterprise Management Improvement and

15 They use top-30 chaebols. 
Privatization Act." According to this act, the companies have to disclose in the proxy statement detailed performance evaluation and compensation contract of the CEO. The Act also explicitly states that CEO compensation should be linked to firm performance. Currently, there is a movement to disclose cash compensation of individual board members, but no agreement has been reached among the relevant Ministries.

\section{Data and Empirical Strategy}

We assembled for the first time a pooled cross-sectional time-series dataset on 246 firms that were included in KOSPI200 for at least two consecutive years from 1998 to $2001 .^{16}$ Specifically, we constructed the dataset by merging the following three separate databases. First, we used annual reports of all firms included in each year’s KOSPI200 for 1998-2001 and collected data on TPAY (total annual cash compensation of all directors), APAY (total annual cash compensation of all directors per director), OPTION ( 1 if the firm uses stock option for executives, 0 otherwise), and OWN (proportion of the total outstanding shares owned by all directors). Second, we assembled data (annually for 1989-2001) on stock returns for all KOSPI200 firms from the Korea Securities Research Institute’s stock market return database. Finally, from the Korea Listed Companies Association (KLCA)’s database, we collected corporate accounting data, such as sales, net income and asset annually for the relevant period for all KOSPI200 firms as well as industry classifications of each firm. All three databases were merged by using unique company codes that are common to all three databases. All value variables were adjusted for inflation using CPI.

16 The KOSPI 200, which is underlying index for stock index futures and options trading, is composed of 200 blue chips and accounts for about 90 percent of the total market capitalization. The constituent stocks are selected on the basis of the market value of the individual stocks, liquidity and their relative positions in the industry groups they belong. Its base date is January 3,1990 and the base index is 100 . There were five SOEs listed in the KSE during our sample period and we excluded them from the analysis (we are grateful to the referee for suggesting the exclusion of these SOEs from the analysis). 
Most empirical studies on executive compensation use data on compensation for individual executives (typically CEOs) of U.S. firms, ${ }^{17}$ and perhaps the closest study to ours in terms of the nature of compensation data is Kaplan (1994) that used similar aggregate compensation data for Japanese firms listed in Tokyo Stock Exchange and studied the pay-performance relations for Japanese directors. We begin with estimating the pay-stock performance "semi-elasticities" equations, ${ }^{18}$ as in Kaplan (1994). That is,

$$
\Delta \ln (\mathrm{PAY})_{\mathrm{it}}=\alpha+\beta_{\mathrm{r}} \mathrm{ROR}_{\mathrm{it}}+\mathrm{u}_{\mathrm{it}}
$$

where PAY ${ }_{\text {it }}$ is executive compensation of Firm i in Year t, measured by TPAY it (total annual cash compensation of all directors in 1995-constant won) and APAY it(per director total annual cash compensation of all directors in 1995-constant won); $\mathrm{ROR}_{\mathrm{it}}$ is stock returns of Firm $\mathrm{i}$ in Period t. For the disturbance term, $\mathrm{u}_{\mathrm{i}}$, we assume $\mathrm{u}_{\mathrm{it}} \sim \operatorname{NID}\left(0, \sigma^{2}\right)$. The value of $\beta_{\mathrm{r}}$ indicates the responsiveness of pay to stock returns (or a semi-elasticity of pay with respect to stock returns). Since the pay variable is first-differenced, all firm fixed effects that may affect the level of pay are controlled for (we used first-differences so that we can compare our study to prior studies that tend to use first differences rather than estimating fixed effects directly).

We will then test the robustness of the above baseline model estimates on the pay-stock performance link by considering: (i) year effects; (ii) the use of stock option; (iii) proportion of stock owned by all directors; (iv) lagged performance; (v) industry dummy variables; and (vi) alternative performance measures (such as accounting profitability and sales).

Next, to test our hypothesis developed in the previous section that the pay-performance relations are stronger for non-Chaebol firms than for Chaebol firms, we classify all firms into Chaebol and non-Chaebol firms by going over the Korea Fair Trade Commission (KFTC) press

\footnotetext{
17 See, for example, Murphy (1999) and Rosen (1990) for an excellent survey of the literature.

18 See Rosen (1990).
} 
releases on large business groups. Following most prior studies on Korean Chaebols, we used top 30 Chaebols and then estimate pay-performance relations for non-Chaebol firms and Chaebol firms separately. To see if the results are sensitive to the use of alternative definitions of Chaebols, we repeat the same analysis using top 10 Chaebols and top 50 Chaebols instead of top 30 Chaebols. Furthermore, we will test if the observed difference in pay-performance link between non-Chaebol and Chaebol firms disappears once we account for a possible size effect on pay-performance link.

Descriptive statistics for key variables are summarized in Table 1 where all value variables are in 1995-constant won. Over the sample period of 1998-2001 total cash compensation of all directors of KOSPI200 firms was on average about 1.5 billions of 1995-constant won and the average director earned approximately 103 millions of 1995-constant won. Chaebol firms tend to pay their directors more than non-Chaebol firms (2.3 billions of 1995-constant won vs. 0.9 billions of 1995-constant won for TPAY and 137 millions vs. 79 millions for APAY).

The ratio of the average executive compensation to the average wage of workers in manufacturing in Korea turns out to be 5.6, using average manufacturing worker wage (compiled by the ILO) in Korea during the same time period. Similar aggregate compensation data for all directors of exchange-listed firms in recent years are reported in Kubo (2001) for Japan and Kato and Long (2004) for China. Using these data and ILO data on average manufacturing worker wage data, we found that the ratio of average executive pay to average manufacturing worker wage was 4.2 for Japan in 1995-96 and 7.6 for China in 1998-2002. The average executive in Korea’s listed firms appears to be better paid (relative to the average worker in manufacturing) than its counterpart in Japan yet paid less (relative to the average worker in manufacturing) than 
the Chinese counterpart. ${ }^{19}$

Over the sample period total cash compensation of all directors rose by 9.3 percent per year in real terms whereas the average director's cash compensation increased by 10.4 percent per year. A gap in the pay increase between Chaebol and no-Chaebol firms is small.

The average rate of inflation-adjusted stock return was 2.5 percent over the sample period and it was higher for non-Chaebol firms than for Chaebol firms (3.0 vs. 1.7 percent). The data also show a modest fall in ROA on average each year over the sample period (0.3 percentage-point falls). $\quad$ Non-Chaebol firms experienced a fall (0.7 percentage-point fall) whereas Chaebol firms actually enjoyed a slight increase (0.1 percentage-point increase). Overall, sales grew over the sample period by 15.9 percent per year in real terms. Chaebol firms grew faster than non-Chaebol firms (17.6 vs. 14.7 percent). Finally, the average likelihood of making a negative net income was about 10 percent for all firms. Non-Chaebol firms are much more likely to make a negative net income than Chaebol firms (14.2 vs. 4.5).

Finally, the table also shows that 9 percent of firms used stock option for their directors, and the average firm in our sample had over 10 percent of its stock owned internally by their directors.

\section{$\underline{\text { VI. Results }}$}

Column (i) of Table 2 shows the OLS estimates of Eq. (1) for our full sample including

${ }^{19}$ Comparing the ratio of executive pay/average worker pay between Korea and other industrialized nations such as the U.S., Canada and the U.K. is particularly difficult since the literature on executive compensation in these countries tends to focus on CEO pay rather than average executive pay. For cross-national studies of executive compensation, see for example Kato and Rockel (1992), Kaplan (1994), Abowd and Bognanno (1995), Zhou (1999), and Conyon and Murphy (2000). 
both Chaebol and non-Chaebol firms, using total annual cash compensation of all directors (TPAY). The estimated coefficient on stock returns is positive and statistically significant at the 5 percent level, suggesting that a 100 percent increase in stock price will result in a 23 percent increase in total annual cash compensation of all directors. Such magnitude of the responsiveness of pay to stock returns is comparable to what Kaplan (1994) found for Japan.

Column (ii) of Table 2 presents a robustness test concerning year effects. As shown in the table, when year effects are included, the estimated coefficient on stock returns is still statistically significant at the 10 percent level although it falls somewhat to 0.192 . To further confirm the insignificant impact of year effects, the estimated coefficient on each year dummy variable is not significant even at the 10 percent level, pointing to the insignificance of the time dummy variables individually. Moreover, F-test cannot refute the joint exclusion of the two time dummy variables from the model even at the 10 percent level, pointing to the insignificance of the time dummy variables jointly. ${ }^{20}$

Column (iii) of Table 2 provides an account of whether the significant pay-stock return link obtained earlier changes when stock option is considered. We consider the stock option dummy variable OPTION (=1 if the firm uses stock option for their executives, 0 otherwise) and an interaction term involving the stock option dummy variable and stock returns, OPTION*ROR. The estimated coefficient on OPTION captures the direct impact on pay growth of the use of stock option whereas the estimated coefficient on OPTION*ROR gauges the effect on pay-performance link of the use of stock option. The table shows that the estimated coefficient on neither OPTION nor OPTION*ROR is statistically significant at the 10 percent level, and that

\footnotetext{
${ }^{20}$ In the literature there appears to be no strong consensus on the use of year dummy variables. For example, Kaplan (1994) considers year dummy variables whereas Murphy (1999) does not.
} 
F-test cannot reject the joint exclusion of the two stock option variables even at the 10 percent level. In short, we find no statistically significant effect on pay growth and pay-performance link of the use of stock option. Not surprisingly, Column (iii) of Table 2 confirms that even when stock option is considered, the estimated coefficient on ROR is still positive and statistically significant at the 5 percent level (or there is statistically significant pay-performance link).

Column (iv) of Table 2 presents a similar robustness test result concerning insider ownership. As shown in the table, even if we consider OWN (proportion stock owned by all directors) and OPTION*ROR, the estimated coefficient on ROR is still positive and statistically significant at the 5 percent level. As in the case of OPTION, we find no statistically significant effect on pay growth and pay-performance link of OWN (the estimated coefficient neither on OWN nor on OWN*ROR is statistically significant at the 10 percent level and F-test cannot reject the joint exclusion of OWN and OWN*ROR at the 10 percent level). .

The next column provides yet another robustness test result. The estimated coefficient on lagged stock returns is shown to be highly insignificant whereas the estimated coefficient on contemporaneous stock returns is still statistically significant at the 5 percent level.

Since we use first difference specifications, all firm fixed effects that may affect the level of pay are controlled for. Being part of firm fixed effects, industry-specific effects on pay level are hence controlled for. However, if there are any industry-specific effects on "pay change," as opposed to the "pay level," then we will need to include industry dummy variables in our regressions. Column (vi) shows the results with such industry dummy variables. Specifically, the data allow us to create 20 industry dummy variables consisting of primary; 
construction; food processing, textile; paper and pulp; pharmaceutical; chemical; non-metal; steel; precision instrument; transportation equipment; other manufacturing; retail and wholesale trade; utilities; machinery; electric and electronic machinery; transportation; communication; banking; and service (in the actual regressions, we exclude chemical as a reference category). Reassuringly, the estimated coefficient on ROR turns out to remain positive and statistically significant at the 5 percent level even after adding these industry dummy variables. To be consistent, it turns out that F-test cannot reject the joint exclusion of all these industry dummy variables at the 10 percent level.

Finally, while the vast majority of the literature on executive compensation focuses on the sensitivity of pay to stock market performance, Kaplan (1994) also considers alternative firm performance measures such as accounting profitability and sales. To test whether the significant pay-stock return semi-elasticity estimates we obtained change when we consider such alternative performance measures, we augment Eq. (1) with three additional performance variables, following Kaplan (1994). That is,

$$
\Delta \ln (\mathrm{PAY})_{\mathrm{it}}=\alpha+\beta_{\mathrm{r}} \mathrm{ROR}_{\mathrm{it}}+\beta_{\mathrm{d}} \Delta \mathrm{ROA}_{\mathrm{it}}+\beta_{\mathrm{g}} \mathrm{SALEGROW}_{\mathrm{it}}+\beta_{\mathrm{n}} \mathrm{NEGPROF}_{\mathrm{it}}+\mathrm{u}_{\mathrm{it}}
$$

where $\mathrm{ROA}_{\mathrm{it}}$ is Return On Asset (Net Income/Asset) of Firm i in Year t; SALEGROW ${ }_{\text {it }}$ is Rate of Growth of Sales of Firm i in Year t; NEGPROF it $_{\text {it }}$ a dummy variable that takes a value of 1 if Firm i's net income in Year $t$ is negative, 0 otherwise.

The value of $\beta_{\mathrm{d}}$ gauges the responsiveness of pay to ROA (or a standard accounting firm performance measure). The sign and significance of the estimated coefficients on SALEGROW $\mathrm{W}_{\mathrm{it}}$ will tell us whether executive compensation is structured so as to reward directors 


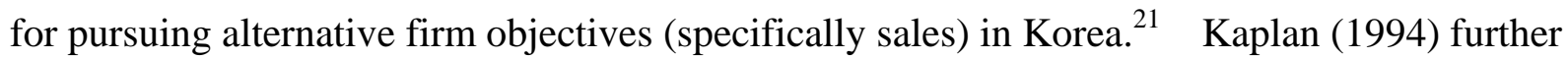
considered NEGPROF it which takes a value of one if the firm i's net income is negative in Year $t$, and found that Japanese executives are indeed penalized significantly when their firm's net income is negative. We test whether this is also the case in Korea by considering this variable here as well.

First, reassuringly Column (vii) of Table 2 confirms that the estimated coefficient on stock returns changes very little and is again statistically significant at the 5 percent level even when controlling for the other three performance variables. As such, the statistically significant link of pay to stock returns appears to be robust.

Second, the estimated coefficient on $\triangle \mathrm{ROA}$ (our accounting performance measure) is positive and statistically significant at the 10 percent level. The size of the estimated coefficients suggest that a 1 percentage-point increase in ROA leads to a 0.7 percent increase in total annual cash compensation of all directors. Again, the size of the responsiveness of pay to ROA found for Korean firms is comparable to what Kaplan (1994) discovered for Japanese firms. The other two alternative performance measures (SALEGROW and NEGPROF) turn out to be not significantly related to pay growth. ${ }^{22}$

Table 3 repeats the same analysis using APAY (total annual cash compensation of all directors per director) instead of TPAY. The estimated coefficients on stock returns are still

${ }^{21}$ Since we use first-difference specifications where the dependent variable is pay growth rather than pay level, as Kaplan (1994) did, our size variable is growth rate of sales.

${ }_{22}$ We also considered two additional specifications. First, we considered industry average ROR as an additional explanatory variable and found no discernable changes in the estimated coefficient on ROR. Second, to account for possible clustering effects of Chaebols, we considered Chaebol dummy variable ( $=1$ if the firm is a Chaebol firm, 0 otherwise) as an additional explanatory variable and again found no discernable differences in the estimated coefficient on ROR. These and other unreported results are available from the corresponding author at tkato@mail.colgate.edu upon request. 
positive yet the coefficients are now less precisely estimated. To further examine why the pay-performance link is less significant with APAY than with TPAY, we added the change in log of the total number of directors (\%growth of board size) as an explanatory variable in the average pay regressions. Reassuringly the significance of the estimated coefficient on stock returns is restored and the size of the estimated coefficient is comparable to the one obtained in the total pay regressions. Furthermore, we find that the estimated coefficient on \%growth of board size is negative and highly significant. In sum, the discrepancy between the total pay regression results and the average pay regression results is due largely to the negative effect on average compensation growth of board size growth. When stock return falls, pay growth will be lower. However, the falling stock return will lead to lower growth of board size which will in turn increase average pay growth. ${ }^{23}$ As a result, the link between average pay growth and stock return will be diluted if one does not control for board size growth.

Table 4 summarizes the OLS estimates of Eq. (2) for non-Chaebol and Chaebol firms separately. $^{24}$ The differences between non-Chaebol and Chaebol firms are pronounced. For non-Chaebol firms the estimated coefficient on stock returns is positive and statistically significant at the 5 percent level while for Chaebol firms the estimated coefficient on stock returns is not significant at the 10 percent level. Moreover, the same pattern emerges for accounting performance, i.e., the estimated coefficient on $\triangle \mathrm{ROA}$ is positive and statistically

${ }^{23}$ It is plausible that Korean firms with deteriorating performance downsize their board size as part of the overall labor force downsizing program. There is anecdotal evidence that when Korean firms try to decrease their board size, they tend to do so by excluding low-rank executives. Since low-rank executives are paid less than other directors, such nonrandom downsizing of the board will result in a higher average compensation.

${ }_{24}$ We also estimated Eq. (1) separately for non-Chaebol and Chaebol firms and found that pay is statistically significantly linked to stock performance for non-Chaebol firms while such pay-performance link does not exist for Chaebol firms. Furthermore, we added the stock option variables and confirmed that our key results (significant pay-performance link for non-Chaebol firms and no such link for Chaebol-firms) do not change when stock option is considered. Likewise, the observed contrast between no-Chaebol and Chaebol firms was found to be insensitive to whether we account for insider ownership, and industry effect. 
significant at the 10 percent level for non-Chaebol firms while there is no statistically significant link between $\triangle$ ROA and pay growth.

When we use APAY, we find similar differences between non-Chaebol and Chaebol firms and actually the differences are even more pronounced. As shown in the table, the estimated coefficient on stock returns for non-Chaebol firms is positive and statistically significant at the 5 percent level. In contrast, the estimated coefficients on stock returns for Chaebol firms are not at all statistically significant (in fact negative). ${ }^{25}$ The findings support our hypothesis developed earlier that executive compensation is more strongly linked to firm performance (in particular stock returns) in non-Chaebol firms than in Chaebol firms.

As most prior studies on Korean Chaebols did, we determine whether the firm is a Chaebol or non-Chaebol firm, using a list of top 30 Chaebols as in the case of most prior studies on Chaebols. To see if the results change when we use alternative definitions of Chaebols, we repeat the above analysis using top 10 Chaebols and top 50 Chaebols instead of top 30 Chaebols. The results are shown in Table $5 .^{26}$ The table confirms that our key finding is robust to the use of alternative definitions of Chaebols, i.e., whether top 30 Chaebols, top 10 Chaebols, or top 50 Chaebols are used, executive compensation is positively and significant related to stock return in non-Chaebol firms while such a significant and positive relationship between pay and stock return does not exist for directors of Chaebol firms.

Finally, prior studies suggest and provide evidence on an inverse relationship between pay-performance sensitivities and firm size (see for example Gibbons and Murphy, 1992,

${ }^{25}$ When we control for \%board size growth, the estimated coefficient on stock returns becomes positive yet still statistically insignificant (the estimated coefficients on \%board size growth are negative and highly significant). The lack of the pay-performance link for Chaebol firms appears to be robust.

${ }^{26}$ Though not shown in the table, we obtain the same robustness result with APAY instead of TPAY. 
Schaefer, 1998, and Murphy 1999). It is well known that non-Chaebol firms are smaller than Chaebol firms, and according to our data, the average Chaebol firm (using top 30 Chaebols)'s total asset was nearly 30 percent larger than the average non-Chaebol firms (3.6 billion vs. 2.8 billion). The observed contrast in pay-performance link between non-Chaebol and Chaebol firms may be due to the simple fact that our non-Chaebol sample comprised of relatively more small firms than our Chaebol sample.

To examine whether this is indeed the case, we exclude small firms from our non-Chaebol sample and re-estimate semi-elasticities of pay with respect to stock return for such a restrictive non-Chaebol sample to see if we still find positive and significant semi-elasticities of pay with respect to stock return for non-Chaebol firms whereas finding no such pay-performance link for Chaebol firms. We first calculate the $25^{\text {th }}$ percentile of total asset for our non-Chaebol firm sample and exclude smallest 25 percent of non-Chaebol firms (to contrast the results, we also exclude any Chaebol firms with their total asset less than the same cut-off level of total asset). ${ }^{27}$ Columns (i) and (ii) of Table 6 present the results. Even after excluding smallest $25 \%$ firms from the non-Chaebol sample, we still find a positive and statistically significant (at the 5 percent level) relationship between executive compensation and stock return whereas we still find no such relationships for the Chaebol sample (it turns out that all Chaebol firms have their levels of total asset exceeding the $25^{\text {th }}$ percentile of the non-Chaebol sample and thus the estimates in Column (ii) is identical to Column (ii) of Table 4).

To further test the robustness of the results, we exclude more small firms from the non-Chaebol sample by using the medium value of total asset as an alternative cut-off value.

\footnotetext{
${ }^{27}$ We also consider market cap as an alternative measure of size and repeat the same analysis. Reassuringly we find no discernable differences. Measuring firm size with asset and market cap appears to be standard in the literature (see, for example, Schaefer, 1998).
} 
As shown in Columns (iii) and (iv) of Table 6, even after dropping smallest 50 percent of firms from the non-Chaebol sample, the estimated semi-elasticity of executive compensation with respect to stock return remain statistically significant at the 5 percent level for non-Chaebol firms whereas it remains insignificant even at the 10 percent level for Chaebol firms. In short, the observed difference in pay-performance link between non-Chaebol and Chaebol firms remains valid even after excluding small firms from the non-Chaebol sample.

An alternative way to account for the possible size effect on pay-performance sensitivities is to estimate the elasticity of pay with respect to shareholder value by regressing $\Delta \ln (\mathrm{PAY})_{\mathrm{it}}$ on $\ln \left(1+\mathrm{ROR}_{\mathrm{it}}\right)$, following Gibbons and Murphy (1992) and Murphy (1999) who argue that such pay-performance elasticities are relatively invariant to firm size. As shown in Table 7, to be consistent with our earlier estimates, for all firms, the estimated elasticity of pay with respect to shareholder value is positive and statistically significant at the 5 percent level when TPAY is used; and for non-Chaebol firms, the estimated elasticity of pay with respect to shareholder value is positive and statistically significant at the 5 percent level regardless of the choice of pay variables (TPAY or APAY). The sizes of the estimated elasticities range from 0.29 to 0.34 , suggesting a 10 percent increase in shareholder value leading to around 3 percent increase in annual cash compensation of Korean directors. The Korean pay-performance elasticity estimates that we obtained are similar to what Murphy (1999) found for S\&P 500 Industrials in the U.S. in the first half of the 1990s. ${ }^{28}$

${ }^{28}$ Since the use of stock option is more limited in Korea than in the U.S., it may well be still the case that the total financial incentive of top executives to pursue shareholder value is considerably stronger in the U.S. than in Korea. See, for example, Hall and Murphy (2003) and Bebchuk and Fried (2003) for succinct discussions on the recent literature on U.S. executive compensation which tends to focus on stock options. However, since stock option is equally limited in Japan, we can probably safely conclude that the total financial incentive of top executives of non-Chaebol firms in Korea is comparable to Japan. 
Perhaps more importantly, however, Table 7 shows that for Chaebol firms the estimated elasticity of pay with respect to shareholder value is not significant even at the 10 percent level (in fact it has a wrong sign in the case of APAY). In other words, using the alternative elasticity specification which is less variant to firm size, we still find that executive pay is significantly linked to firm performance in non-Chaebol firms yet not so in Chaebol firms. In sun, both sets of results summarized in Tables 6 and 7 point to the robustness of our observed difference in pay-performance link between non-Chaebol and Chaebol firms.

\section{$\underline{\text { V. Conclusions }}$}

This paper has provided the first rigorous econometric estimates on pay-performance relations for directors of leading Korean firms with and without Chaebol affiliation. To do so, we have assembled for the first time panel data (that provide information not only on executive compensation and firm performance but also on Chaebol affiliation) for 246 firms that were included in KOSPI200 for at least two consecutive years from 1998 to 2001.

Contrary to a popular belief that Korean corporate governance and the structure of Korean executive compensation is greatly different from elsewhere in the West, we have found that cash compensation of Korean executives is statistically significantly related to stock market performance and that the magnitude of the responsiveness of pay to stock market performance is comparable to Japan (and the U.S. insofar as cash compensation is concerned). Perhaps even more importantly, further analysis has revealed for the first time that such overall significant executive pay-performance link is driven by non-Chaebol firms and that no such link exists for 
Chaebol firms. $^{29}$ As such, our study complements earlier Korean-language works which tend to point to significant executive pay-performance relations in Korea in general. ${ }^{30}$

Our evidence is also consistent with the recent literature on the nature of Chaebols in Korea. The controlling families of a Chaebol group have been criticized for running the affiliated firms as a vehicle to enrich their own personal wealth, and not necessarily the wealth of shareholders in those individual companies. It has been alleged that a Chaebol sometimes instructs its member firm to transfer wealth to a member firm under financial distress via illegal related-party transactions. Such 'tunneling' may be consistent with the interest of the controlling family and the group as a whole yet it is done at the expense of outside shareholders of the firm that is instructed to transfer its wealth to the troubled affiliate firm. Also, the controlling family from time to time allegedly enters a new risky business indirectly through its affiliate, of which the family does not have a direct equity ownership. As such, the controlling family can minimize the risk of making a direct loss at the cost of outside shareholders of the affiliate.

Corporate governance reform efforts since the financial crisis of 1997/98 has been targeting at such tunneling activities. Specific examples of such reform efforts include the mandatory adoption of a 50\% outside director ratio, audit committee, and outside director nomination committee for firms with book asset size greater than 2 trillion, the adoption of

${ }^{29}$ There is a growing literature on the link between ownership structure and executive compensation in advanced industrialized nations. See, for example, Core, Holthausen, and Larcker (1999), Ke, Petroni, and Safieddine (1999), Harvey and Shrieves (2001), Bertrand and Mullainathan (2001), Cyert, Kang and Kumar (2002) and Hartzell and Starks (2003) for the U.S.; Conyon (1997), Cosh and Hugh (1997), and Cragg and Dyck (2003) for the U.K.; Kato (1997) for Japan; Elston and Goldberg (2002) for Germany; and Randoy and Nielsen (2002) for Norway and Sweden. For transition economies, see for instance, Jones and Kato $(1996,1998)$ for Bulgaria, Jones and Mygind (2004) for Estonia, and Kato and Long (2004) for China.

30 See, for example, Hwang (1995), Kim, Chung and Ji (1999), and Shin, Lee and Chang (2003). 
cumulative voting in the Commercial Code, and the proposed class action lawsuit. ${ }^{31}$ The adoption of compensation committee and the disclosure of individual director's cash compensation are being considered in a similar context. ${ }^{32}$

Campbell and Keys (2002) point to poorer corporate governance of Chaebol firms as compared to non-Chaebol firms by showing that Chaebol firms underperform non-Chaebol firms financially and that top executive turnover is not significantly related to firm performance for Chaebol firms whereas it is for non-Chaebol firms. Linking executive turnover to firm performance is, however, not the only internal corporate governance mechanism to discipline poorly performing top managers and reward well performing top managers, and hence alleviate the agency problem. Making their pay sufficiently sensitive to firm performance (pay-performance sensitivity) is potentially equally important. It is plausible that Chaebol firm’s poor functioning of internal corporate governance in terms of the lack of turnover-performance sensitivities could be compensated for by the presence of strong pay-performance sensitivities. Our study rejects this possibility by showing that pay-performance sensitivities are also non-existent for Chaebol firms whereas they do exist for non-Chaebol firms in Korea. As such, our study complements Campbell and Keys (2002), together making a strong case that Chaebol firms in Korea do not have well functioning internal corporate governance. ${ }^{33}$ As such, the present Korean corporate governance reform efforts that are aimed at Chaebol firms seem to be supported by evidence.

In our future work, we will investigate the impact on pay-performance link of such

${ }^{31}$ Despite such adoption in the Commercial Code, with a provision in their articles of incorporation, most Korean firms exempt themselves from cumulative voting. The bill for securities class action lawsuit, first submitted in 2001, passed the National Assembly in December 2003.

32 Such proposals have been made recently by Korea Corporate Governance Service and Korea Development Institute.

${ }^{33}$ For a more detailed and institutional account of corporate governance problems in Chaebol firms, see for example Nam and Nam (2004). 
reform measures. To do so, we will need to continue to collect the executive compensation data in the coming years as corporate governance reform progresses, in particular the proposed adoption of the compensation committee system and disclosure of individual director's cash compensation are implemented. 


\section{$\underline{\text { References }}$}

Abowd, John M., and Michael L. Bognanno, 1995, International Differences in Executive and Managerial Compensation, in Differences and changes in wage structures (University of Chicago Press, Chicago and London).

Ahmadjian, Christina, 2001, Changing Japanese Corporate Governance,, (Center on Japanese Economy and Business Working Paper No. 188, Columbia Business School).

Ang, James S. , and Richard L. Constand, 1997, Compensation and Performance: The Case of Japanese Managers and Directors, Journal of Multinational Financial Management 7, 275-304.

Bae, Kee-Hong, Jun-Koo Kang, and Jin-Mo Kim, 2002, Tunneling or Value Added? Evidence from Mergers by Korean Business Groups, Journal of Finance 57, 2695-2740.

Baek, Jae-Seung, Jun-Koo Kang, and Kyung Suh Park, 2004, Corporate Governance and Firm Value: Evidence from the Korean Financial Crisis, Journal of Financial Economics 71, 265-313.

Bebchuk, Lucian Arye, and Jesse M. Fried, 2003, Executive Compensation as an Agency Problem, Journal of Economic Perspectives 17, 71-92.

Bertrand, Marianne, and Sendhil Mullainathan, 2001, Are CEOs Rewarded for Luck? The Ones without Principles Are, Quarterly Journal of Economics 116, 901-32.

Black, Bernard S, Jang Hasung, and Woochan Kim, 2003, Does Corporate Governance "Predict Firms' Market Values? Evidence from Korea, (John M. Olin Program in Law and Economics Working Paper No. 237).

Campbell, Terry L., II, and Phyllis Y. Keys, 2002, Corporate Governance in South Korea: The chaebol Experience, Journal of Corporate Finance: Contracting, Governance and Organization 8, 373-91.

Choe, Heungsik, and Bong-Soo Lee, 2003, Korean Bank Governance Reform after the Asian Financial Crisis, Pacific-Basin Finance Journal 11, 483-508.

Claessens, Stijn , Simeon Djankov, Joseph P.H. Fan, and Larry H.P. Lang, 2002, Disentangling the Incentive and Entrenchment Effects of Large Shareholdings, Journal of Finance 57, 2741.

Claessens, Stijn, Simeon Djankov, and Larry H. P. Lang, 2000, The Separation of Ownership and Control in East Asian Corporations, Journal of Financial Economics 58, 81-112.

Conyon, Martin J., 1997, Corporate governance and executive compensation., International Journal of Industrial Organization 15, 493-509.

Conyon, Martin J., and Kevin J. Murphy, 2000, The Prince and the Pauper? CEO Pay in the United States and United Kingdom, Economic Journal 110, 71.

Core, John E., Robert W. Holthausen, and David F. Larcker, 1999, Corporate Governance, Chief Executive Officer Compensation, and Firm Performance, Journal of Financial Economics 51, 371-406.

Cosh, Andy, and Alan Hughes, 1997, Executive Remuneration, Executive Dismissal and Institutional Shareholdings, International Journal of Industrial Organization 15, 469-92.

Cragg, Michael I., and I. J. Alexander Dyck, 2003, Privatization and Management Incentives: Evidence from the United Kingdom, Journal of Law, Economics, and Organization 19, 176-217. 
Cyert, Richard M., Sok-Hyon Kang, and Praveen Kumar, 2002, Corporate Governance, Takeovers, and Top-Management Compensation: Theory and Evidence, Management Science 48, 453-69.

Gibbons, Robert, 1997, Incentives and Careers in Organizations, Advances in economics and econometrics: Theory and applications: Seventh World Congress. Volume 2 (Cambridge University Press, Cambridge; New York and Melbourne).

Gibbons, Robert, and Kevin J. Murphy, 1992, Optimal Incentive Contracts in the Presence of Career Concerns: Theory and Evidence, Journal of Political Economy 100, 468-505.

Gibbons, Robert, and Michael Waldman, 1999, Careers in Organizations: Theory and Evidence, Handbook of labor economics. Volume 3B (Elsevier Science, North-Holland, Amsterdam; New York and Oxford).

Groves, Theodore, Yongmiao Hong, John McMillan, and Barry Naughton, 1995, China's Evolving Managerial Labor Market, Journal of Political Economy 103, 873-92.

Hall, Brian J., and Kevin J. Murphy, 2003, The Trouble with Stock Options, Journal of Economic Perspectives 17, 49-70.

Hartzell, Jay C., and Laura T. Starks, 2003, Institutional Investors and Executive Compensation, Journal of Finance 58, 2351-74.

Harvey, Keith D., and Ronald E. Shrieves, 2001, Executive Compensation Structure and Corporate Governance Choices, Journal of Financial Research 24, 495-512.

Hwang, In-Tae, 1995, Executive Compensation and Firm Performance (in Korean), Hoi-Gae-Yeun-Ku 20, 108-125.

Joh, Sung Wook, 1999, Strategic Managerial Incentive Compensation in Japan: Relative Performance Evaluation and Product Market Collusion, Review of Economics and Statistics 81, 303-13.

Joh, Sung Wook, 2003, Corporate Governance and Firm Profitability: Evidence from Korea before the Economic Crisis, Journal of Financial Economics 68, 287-322.

Jones, Derek C., and Takao Kato, 1996, The Determinants of Chief Executive Compensation in Transitional Economies: $\quad$ Evidence form Bulgaria, Labour Economics 3, 319-36.

Jones, Derek C., and Takao Kato, 1998, Chief Executive Compensation During Early Transition: Further Evidence from Bulgaria., (William Davidson Working Paper no. 146, University of Michigan).

Jones, Derek C., and Niels Mygind, 2004, Majority Ownership and Executive Compensation, 2004 ASSA Meetings, San Diego, January 3-5.

Jung, Kooyul and Soo Young Kwon, 2002, Ownership structure and earnings informativeness: Evidence from Korea, International Journal of Accounting 37, 301-325.

Kaplan, Steven N., 1994, Top executive rewards and firm performance: A comparison of Japan and the United States, Journal of Political Economy 102, 510-546.

Kato, Takao, 1997, Chief executive compensation and corporate groups in Japan: New evidence from micro data., International Journal of Industrial Organization 15, 455 -67.

Kato, Takao , and Mark Rockel, 1992, Experiences, Credentials, and Compensation in the Japanese and U.S. Managerial Labor Markets: Evidence from New Micro Data, Journal of the Japanese and International Economies 6, 30-51.

Kato, Takao, and Katsuyuki Kubo, 2003, CEO Compensation and Firm Performance in Japan: Evidence from New Panel Data On Individual CEO Pay, (Working Paper No. 210, Center on Japanese Economy and Business, Columbia Business School (forthcoming in Journal of the Japanese and International Economies)). 
Kato, Takao, and Cheryl Long, 2004, Executive Compensation, Firm Performance, and State Ownership in China: Evidence from New Panel Data, William Davidson Institute Working Paper No. 690, May 2004.

Ke, Bin, Kathy Petroni, and Assem Safieddine, 1999, Ownership Concentration and Sensitivity of Executive Pay to Accounting Performance Measures: Evidence from Publicly and Privately-Held Insurance Companies, Journal of Accounting and Economics 28, 185-209.

Kim, Byungmo, and Inmoo Lee, 2003, Agency Problems and Performance of Korean Companies during the Asian Financial Crisis: Chaebol vs. Non-chaebol Firms, Pacific-Basin Finance Journal 11, 327-48.

Kim, Tae-Soo, June-Soo Chung, and Sung-Kwon Ji, 1999, Executive Compensation and Firm Performance in Korea (in Korean), Hoi-Gae-Yeun-Ku 24, 87-115.

Kim, Tae-Soo, June-Soo Chung, and Sung-Kwon Ji, 1999a, Executive Compensation and Firm Performance in Korea (in Korean), Hoi-Gae-Yeun-Ku 24.

Kubo, Katsuyuki, 2001, The Determinants of Executive Compensation in Japan and the UK: Agency Hypothesis or Joint Determination Hypothesis?, in M. Hanazaki, J. Fan, and J. Teranishi, eds.: Designing Financial Systems for East Asia and Japan, forthcoming (Routledge, London).

Lemmon, Michael L., and Karl V. Lins, 2003, Ownership Structure, Corporate Governance, and Firm Value: Evidence from the East Asian Financial Crisis, Journal of Finance 58, 1445-68.

Mitton, Todd, 2002, A Cross-Firm Analysis of the Impact of Corporate Governance on the East Asian Financial Crisis, Journal of Financial Economics 64, 215-41.

Murphy, Kevin J., 1999, Executive Compensation, in Handbook of labor economics. Volume 3B (Elsevier Science, North-Holland, Amsterdam; New York and Oxford).

Nam, Sang-Woo, 2002, Employees in Asian Enterprises: Their Potential Role in Corporate Governance, (Discussion Paper, Asian Development Bank Institute).

Nam, Sang-Woo, and Il Chong Nam, 2004, Corporate Governance in Asia: Recent Evidence from Indonesia, Republic of Korea, Thailand and Malaysia, (Unpublished manuscript, Asian Development Bank Institute).

Rosen, Sherwin, 1990, Contracts and the Market For Executives, (NBER Working Paper, no. 3542, National Bureau of Economic Research).

Schaefer, Scott, 1998, The Dependence of Pay-Performance Sensitivity on the Size of the Firm, Review of Economics and Statistics 80, 436-43.

Shin, Hyun-Han, Man-Yong Lee, and Jinho Chang, 2003, Empirical Evidence on Executive Compensation Structure (in Korean), (Unpublished manuscript).

Shin, Hyun-Han, and Young S. Park, 1999, Financing Constraints and Internal Capital Markets: Evidence from Korean 'Chaebols.' Journal of Corporate Finance: Contracting, Governance and Organization 5, 169-91.

World-Bank, 2003, the Report on the Observance of Standards and Codes (ROSC): Corporate Governance Country Assessment Republic of Korea.

$\mathrm{Xu}$, Peng, 1997, Executive Salaries as Tournament Prizes and Executive Bonuses as Managerial Incentives in Japan, Journal of the Japanese and International Economies 11, 319-46.

Zhou, Xianming, 1999, Executive Compensation and Managerial Incentives: A Comparison between Canada and the United States, Journal of Corporate Finance: Contracting, Governance and Organization 5, 277-301. 
Table 1 Summary Statistics

\begin{tabular}{|c|c|c|c|c|c|c|c|c|c|}
\hline & \multicolumn{3}{|l|}{ All Firms } & \multicolumn{3}{|c|}{ Non-Chaebol Firms } & \multicolumn{3}{|l|}{ Chaebol Firms } \\
\hline & Mean & S.D. & $\mathrm{N}$ & Mean & S.D. & $\mathrm{N}$ & Mean & S.D. & $\mathrm{N}$ \\
\hline TPAY & 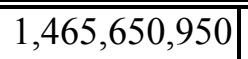 & $2,407,498,520$ & 543 & $867,840,885$ & $830,295,090$ & 323 & $2,343,344,820$ & 3,468,426,470 & 220 \\
\hline$\Delta \ln (\mathrm{TPAY})$ & 0.093 & 0.544 & 543 & 0.094 & 0.552 & 323 & 0.092 & 0.532 & 220 \\
\hline$\Delta \ln (\mathrm{APAY})$ & 0.104 & 0.581 & 539 & 0.112 & 0.479 & 321 & 0.091 & 0.706 & 218 \\
\hline ROR & 0.025 & 0.213 & 543 & 0.030 & 0.250 & 323 & 0.017 & 0.144 & 220 \\
\hline$\Delta \mathrm{ROA}$ & -0.003 & 0.067 & 543 & -0.007 & 0.067 & 323 & 0.001 & 0.065 & 220 \\
\hline SALEGROW & 0.159 & 0.373 & 543 & 0.147 & 0.379 & 323 & 0.176 & 0.364 & 220 \\
\hline NEGPROF & 0.103 & 0.304 & 543 & 0.142 & 0.350 & 323 & 0.045 & 0.209 & 220 \\
\hline
\end{tabular}

(Sources)

1. Data on TPAY (Total Annual Cash Compensation of All Directors) and APAY (Total Annual Cash Compensation of All Directors Per Director) are from Annual report of each company (can be accessed from Korea Stock Exchange or

Financial Supervisory Service websites: http://kind.kse.or.kr/ and http://dart.fss.or.kr/)

2. Data on Stock Returns are from Korea Securities Research Institute (KSRI).

3. Data on Sales growth and ROA are from Korea Listed Companies Assocation (KLCA).

(Notes)

1. The data are based on 251 firms that were included in KOSPI200 for at least two consecutive years over the sample period of 1998 to 2001 .

2. Variable definitions:

TPAY=Total annual cash compensation of all directors in 1995-constant won;

APAY $=$ Total annual cash compensation of all directors per director in 1995-constant won; ROR==Stock Returns;

OPTION=1 if the firm uses stock option for executives, 0 otherwise;

OWN=proportion stock owned by all directors; ROA=Return On Asset (Net Income/Asset); SALEGROW=Rate of Growth of Sales;

$\mathrm{NEGPROF}=1$ if net income is negative, 0 otherwise. 
Table 2 Regression of Percentage Change in Annual Cash Compensation of All Directors on Stock Returns:

Dependent variable $=\Delta \ln (\mathrm{TPAY})$

\begin{tabular}{|c|c|c|c|c|c|c|c|c|c|c|c|c|c|c|}
\hline & \multicolumn{2}{|l|}{ (i) } & \multicolumn{2}{|c|}{ (ii) } & \multicolumn{2}{|l|}{ (iii) } & \multicolumn{2}{|c|}{ (iv) } & \multicolumn{2}{|l|}{ (v) } & \multicolumn{2}{|c|}{ 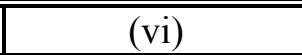 } & \multicolumn{2}{|l|}{ (vii) } \\
\hline & $\beta$ & t-value & $\beta$ & $\mathrm{t}$-value & $\beta$ & t-value & $\beta$ & t-value & $\beta$ & t-value & $\beta$ & t-value & $\beta$ & t-value \\
\hline Constant & $0.088 * * *$ & 3.743 & 0.056 & 1.395 & $0.092 * * *$ & 3.743 & $0.100 * * *$ & 3.149 & $0.088 * * *$ & 3.729 & $0.126 * *$ & 2.322 & $0.095 * * *$ & 3.512 \\
\hline ROR & $0.233 * *$ & 2.131 & $0.192 *$ & 1.647 & $0.216 *$ & 1.898 & $0.233 *$ & 1.620 & $0.233 * *$ & 2.127 & $0.261 * *$ & 2.320 & $0.235 * *$ & 2.145 \\
\hline YEAR98 & & & 0.080 & 1.324 & & & & & & & & & & \\
\hline YEAR99 & & & 0.026 & 0.443 & & & & & & & & & & \\
\hline OPTION & & & & & -0.041 & -0.498 & & & & & & & & \\
\hline OPTION*ROR & & & & & 0.159 & 0.363 & & & & & & & & \\
\hline OWN & & & & & & & -0.114 & -0.586 & & & & & & \\
\hline OWN*ROR & & & & & & & -0.024 & -0.028 & & & & & & \\
\hline $\mathrm{ROR}_{-1}$ & & & & & & & & & 0.000 & 0.010 & & & & \\
\hline $\begin{array}{l}\text { Industry dummy } \\
\Delta \mathrm{ROA}\end{array}$ & No & & No & & No & & No & & No & & Yes & & No & 1812 \\
\hline SALEGROW & & & & & & & & & & & & & -0.062 & -0.944 \\
\hline NEGPROF & & & & & & & & & & & & & 0.044 & 0.538 \\
\hline Obs. & 543 & & 543 & & 543 & & 543 & & 543 & & 543 & & 543 & \\
\hline $\mathrm{R}^{2}$ & 0.0083 & & 0.0117 & & 0.0092 & & 0.0090 & & 0.0095 & & 0.0485 & & 0.0147 & \\
\hline
\end{tabular}

(Sources)

1. Data on TPAY (Total Annual Cash Compensation of All Directors) are from Annual report of each company (can be accessed from

Korea Stock Exchange or Financial Supervisory Service websites: http://kind.kse.or.kr/ and http://dart.fss.or.kr/)

2. Data on Stock Returns are from Korea Securities Research Institute (KSRI).

(Notes)

1. The data are based on 251 firms that were included in KOSPI200 for at least two consecutive years

over the sample period of 1998 to 2001.

2. Variable definitions:

TPAY=Total annual cash compensation of all directors in 1995-constant won; ROR==Stock Returns; $\mathrm{ROR}_{-1}=$ Stock Returns in the previous year;

YEAR98=if $\Delta \ln$ (TPAY) is from 1998 to 1999,0 otherwise; YEAR99=if $\Delta \ln$ (TPAY) is from 1999 to 2000, 0 otherwise;

YEAR00 =if $\Delta \ln (\mathrm{TPAY})$ is from 2000 to 2001,0 otherwise; OPTION $=1$ if the firm uses stock option for executives, 0 otherwise;

OWN=proportion stock owned by all directors; ROA=Return On Asset (Net Income/Asset); SALEGROW=Rate of Growth of Sales;

NEGPROF $=1$ if net income is negative, 0 otherwise.

Industry dummy $=$ a vector of 19 industry dummy variables consisting of primary; construction; food processing, textile;

paper and pulp; pharmaceutical; non-metal; steel; machinery; electric and electronic machinery;

precision instrument; transportation equipment; other manufacturing; retail and wholesale trade; utilities;

transportation; communication; banking; and service (chemical is omitted as a reference category). 
Table 3 Regression of Percentage Change in Annual Cash Compensation of All Directors Per Director on Stock Returns:

Dependent variable $=\Delta \ln ($ APAY $)$

\begin{tabular}{|c|c|c|c|c|c|c|c|c|c|c|c|c|c|c|}
\hline & \multicolumn{2}{|l|}{ (i) } & \multicolumn{2}{|l|}{ (ii) } & \multicolumn{2}{|l|}{ (iii) } & \multicolumn{2}{|c|}{ (iv) } & \multicolumn{2}{|l|}{ (v) } & \multicolumn{2}{|c|}{ (vi) } & \multicolumn{2}{|l|}{ (vii) } \\
\hline & $\beta$ & t-value & $\beta$ & t-value & $\beta$ & t-value & $\beta$ & t-value & $\beta$ & t-value & $\beta$ & t-value & $\beta$ & t-value \\
\hline Constant & $0.100 * * *$ & 3.979 & $0.112 * *$ & 2.594 & $0.092 * * *$ & 3.472 & $0.118 * * *$ & 3.444 & $0.101 * * *$ & 4.007 & 0.081 & 1.369 & $0.105 * * *$ & 3.596 \\
\hline ROR & 0.132 & 1.123 & 0.146 & 1.171 & 0.136 & 1.112 & 0.167 & 1.087 & 0.204 & 1.281 & 0.135 & 1.107 & 0.132 & 1.117 \\
\hline YEAR98 & & & -0.032 & -0.494 & & & & & & & & & & \\
\hline YEAR99 & & & -0.006 & -0.095 & & & & & & & & & & \\
\hline OPTION & & & & & 0.098 & 1.083 & & & & & & & & \\
\hline OPTION*ROR & & & & & 0.109 & 0.233 & & & & & & & & \\
\hline OWN & & & & & & & -0.163 & -0.779 & & & & & & \\
\hline OWN*ROR & & & & & & & -0.368 & -0.402 & & & & & & \\
\hline $\mathrm{ROR}_{-1}$ & & & & & & & & & 0.058 & 0.471 & & & & \\
\hline $\begin{array}{l}\text { Industry dummy } \\
\Delta \mathrm{ROA}\end{array}$ & No & & No & & No & & No & & No & & Yes & & No & 0310 \\
\hline SALEGROW & & & & & & & & & & & & & -0.035 & -0.497 \\
\hline NEGPROF & & & & & & & & & & & & & 0.009 & 0.101 \\
\hline Obs. & 539 & & 539 & & 539 & & 539 & & 539 & & 539 & & 539 & \\
\hline $\mathrm{R}^{2}$ & 0.0023 & & 0.0029 & & 0.0045 & & 0.0039 & & 0.0032 & & 0.0257 & & 0.0029 & \\
\hline
\end{tabular}

(Sources)

1. Data on APAY (Total Annual Cash Compensation of All Directors) are from Annual report of each company (can be accessed from

Korea Stock Exchange or Financial Supervisory Service websites: http://kind.kse.or.kr/ and http://dart.fss.or.kr/)

2. Data on Stock Returns are from Korea Securities Research Institute (KSRI).

(Notes)

1. The data are based on 251 firms that were included in KOSPI200 for at least two consecutive years

over the sample period of 1998 to 2001.

2. Variable definitions:

APAY $=$ Total annual cash compensation of all directors per director in 1995-constant won; ROR $==$ Stock Returns; ROR $_{-1}=$ Stock Returns in the previous year;

YEAR98=if $\Delta \ln$ (TPAY) is from 1998 to 1999,0 otherwise; YEAR99=if $\Delta \ln$ (TPAY) is from 1999 to 2000, 0 otherwise;

YEAR00=if $\Delta \ln ($ TPAY) is from 2000 to 2001,0 otherwise; OPTION $=1$ if the firm uses stock option for executives, 0 otherwise;

OWN=proportion stock owned by all directors; ROA=Return On Asset (Net Income/Asset); SALEGROW=Rate of Growth of Sales;

NEGPROF $=1$ if net income is negative, 0 otherwise.

Industry dummy=a vector of 19 industry dummy variables consisting of primary; construction; food processing, textile;

paper and pulp; pharmaceutical; non-metal; steel; machinery; electric and electronic machinery;

precision instrument; transportation equipment; other manufacturing; retail and wholesale trade; utilities;

transportation; communication; banking; and service (chemical is omitted as a reference category). 
Table 4 Estimating Pay-Performance Relations Separetely for Non-Chaebol and Chaebol Firms

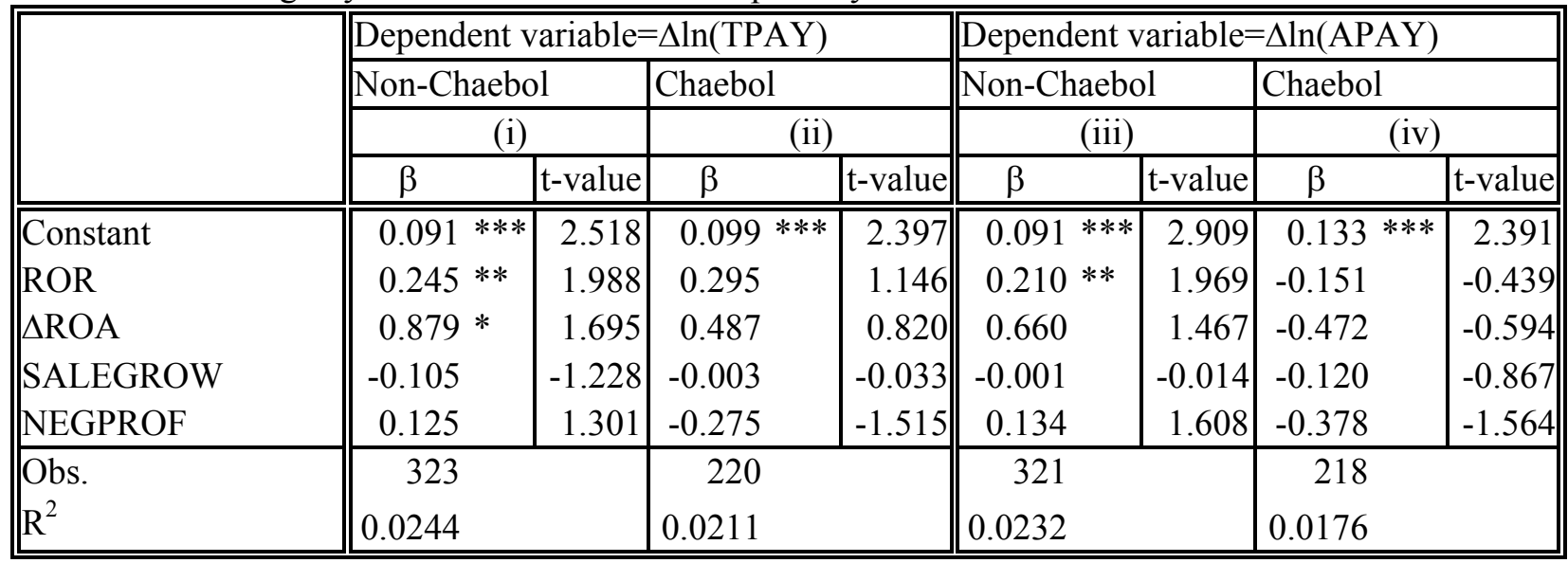

(Sources)

1. Data on TPAY (Total Annual Cash Compensation of All Directors) and

APAY (Total Annual Cash Compensation of All Directors Per Director)

are from Annual report of each company (can be accessed from Korea Stock Exchange or

Financial Supervisory Service websites: http://kind.kse.or.kr/ and http://dart.fss.or.kr/)

2. Data on Stock Returns are from Korea Securities Research Institute (KSRI).

3. Data on Sales growth and ROA are from Korea Listed Companies Assocation (KLCA).

4. We went over the KFTC press releases on large business groups, and

identified for each firm whether it is one of the top 30 Chaebol firms or not.

(Notes)

1. The data are based on 251 firms that were included in KOSPI200

for at least two consecutive years over the sample period of 1998 to 2001.

2. Variable definitions:

TPAY=Total annual cash compensation of all directors in 1995-constant won;

APAY = Total annual cash compensation of all directors per director in 1995-constant won;

$\mathrm{ROR}==$ Stock Returns; ROR-1=Stock Returns in the previous year;

YEAR98=if $\Delta \ln$ (TPAY) is from 1998 to 1999,0 otherwise;

YEAR99=if Dln(TPAY) is from 1999 to 2000, 0 otherwise;

YEAR00 $=$ if $\Delta \ln ($ TPAY) is from 2000 to 2001,0 otherwise;

OPTION=1 if the firm uses stock option for executives, 0 otherwise;

OWN=proportion stock owned by all directors; ROA=Return On Asset (Net Income/Asset);

SALEGROW=Rate of Growth of Sales; NEGPROF $=1$ if net income is negative, 0 otherwise.

Industry dummy $=$ a vector of 19 industry dummy variables consisting of primary; construction;

food processing, textile; paper and pulp; pharmaceutical; non-metal; steel; machinery;

electric and electronic machinery; precision instrument; transportation equipment;

other manufacturing; retail and wholesale trade; utilities; transportation; communication; banking;

and service (chemical is omitted as a reference category). 
Table 5 Estimating Pay-Performance Relations Separetely for Non-Chaebol and Chaebol Firms: alternative definitions of Chaebol Dependent variable $=\Delta \ln ($ TPAY $)$

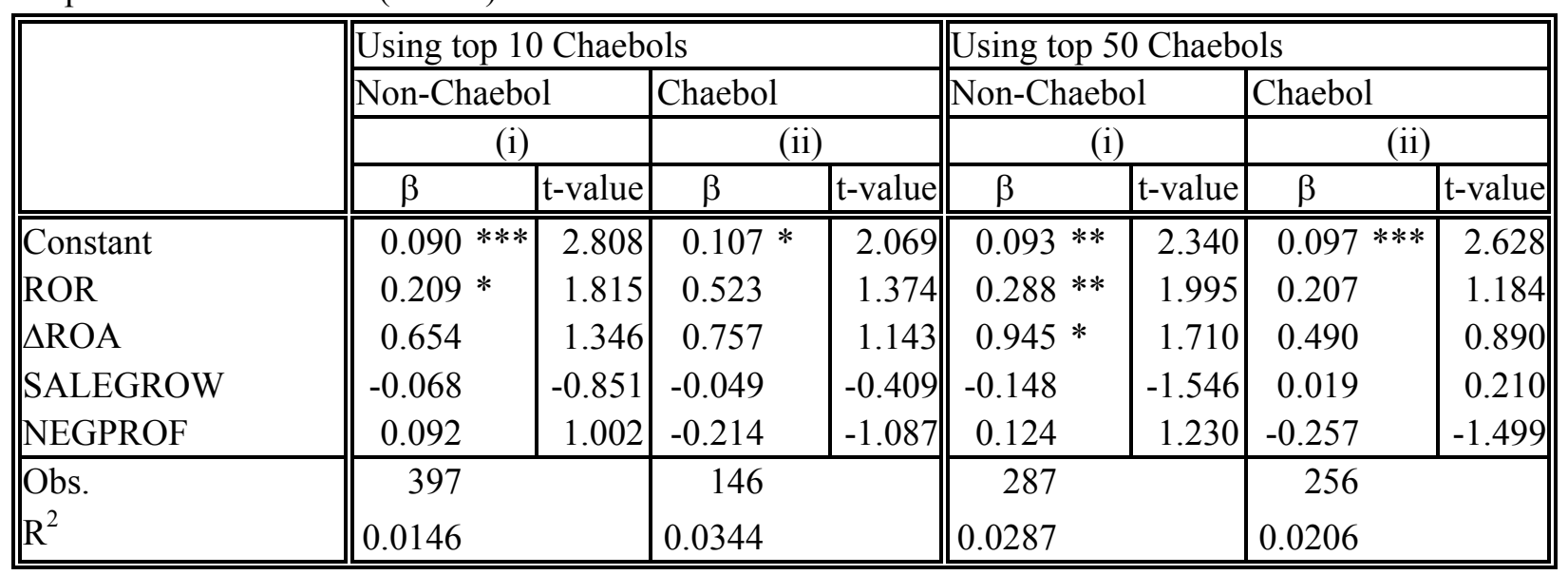

(Sources)

1. Data on TPAY (Total Annual Cash Compensation of All Directors) are from Annual report of each company (can be accessed from Korea Stock Exchange or Financial Supervisory Service websites: http://kind.kse.or.kr/ and http://dart.fss.or.kr/)

2. Data on Stock Returns are from Korea Securities Research Institute (KSRI).

3. Data on Sales growth and ROA are from Korea Listed Companies Assocation (KLCA).

4. We went over the KFTC press releases on large business groups, and identified for each firm whether it is one of the top 10 Chaebol firms or not as well as whether it is one of the top 50 Chaebol firms or not.

(Notes)

1. The data are based on 251 firms that were included in KOSPI200

for at least two consecutive years over the sample period of 1998 to 2001.

2. Variable definitions:

TPAY=Total annual cash compensation of all directors in 1995-constant won;

$\mathrm{ROR}==$ Stock Returns; ROR-1=Stock Returns in the previous year;

YEAR98=if $\triangle \ln$ (TPAY) is from 1998 to 1999,0 otherwise;

YEAR99=if $D \ln ($ TPAY) is from 1999 to 2000, 0 otherwise;

YEAR00 $=$ if $\Delta \ln ($ TPAY) is from 2000 to 2001,0 otherwise;

OPTION=1 if the firm uses stock option for executives, 0 otherwise;

OWN=proportion stock owned by all directors; ROA=Return On Asset (Net Income/Asset);

SALEGROW=Rate of Growth of Sales; NEGPROF $=1$ if net income is negative, 0 otherwise.

Industry dummy=a vector of 19 industry dummy variables consisting of primary; construction;

food processing, textile; paper and pulp; pharmaceutical; non-metal; steel; machinery;

electric and electronic machinery; precision instrument; transportation equipment;

other manufacturing; retail and wholesale trade; utilities; transportation; communication; banking;

and service (chemical is omitted as a reference category). 
Table 6 Estimating Pay-Performance Relations Separetely for Non-Chaebol and Chaebol Firms:

Excluding small firms

Dependent variable $=\Delta \ln ($ TPAY $)$

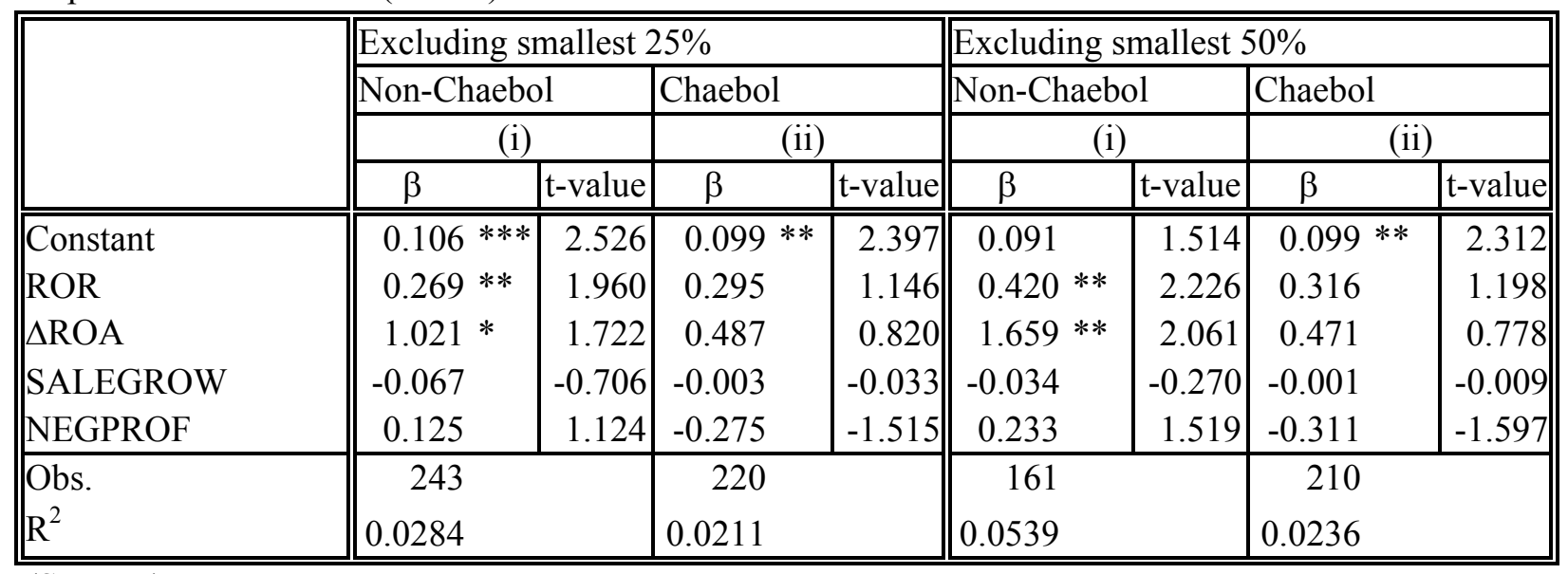

(Sources)

1. Data on TPAY (Total Annual Cash Compensation of All Directors)

are from Annual report of each company (can be accessed from Korea Stock Exchange or

Financial Supervisory Service websites: http://kind.kse.or.kr/ and http://dart.fss.or.kr/)

2. Data on Stock Returns are from Korea Securities Research Institute (KSRI).

3. Data on Sales growth, ROA and assets are from Korea Listed Companies Assocation (KLCA).

4. We went over the KFTC press releases on large business groups, and

identified for each firm whether it is one of the top 10 Chaebol firms or not

as well as whether it is one of the top 50 Chaebol firms or not.

(Notes)

1. The data are based on 251 firms that were included in KOSPI200

for at least two consecutive years over the sample period of 1998 to 2001.

2. Variable definitions:

TPAY=Total annual cash compensation of all directors in 1995-constant won;

$\mathrm{ROR}==$ Stock Returns; ROR-1=Stock Returns in the previous year;

YEAR98=if $\Delta \ln$ (TPAY) is from 1998 to 1999,0 otherwise;

YEAR99=if Dln(TPAY) is from 1999 to 2000, 0 otherwise;

YEAR00 $=$ if $\Delta \ln$ (TPAY) is from 2000 to 2001,0 otherwise;

OPTION=1 if the firm uses stock option for executives, 0 otherwise;

OWN=proportion stock owned by all directors; ROA=Return On Asset (Net Income/Asset);

SALEGROW=Rate of Growth of Sales; NEGPROF $=1$ if net income is negative, 0 otherwise.

Industry dummy=a vector of 19 industry dummy variables consisting of primary; construction;

food processing, textile; paper and pulp; pharmaceutical; non-metal; steel; machinery;

electric and electronic machinery; precision instrument; transportation equipment;

other manufacturing; retail and wholesale trade; utilities; transportation; communication; banking;

and service (chemical is omitted as a reference category).

3. Firm size measured by total asset. 
Table 7 The Elasticities of Pay with Respect to Shareholder Value

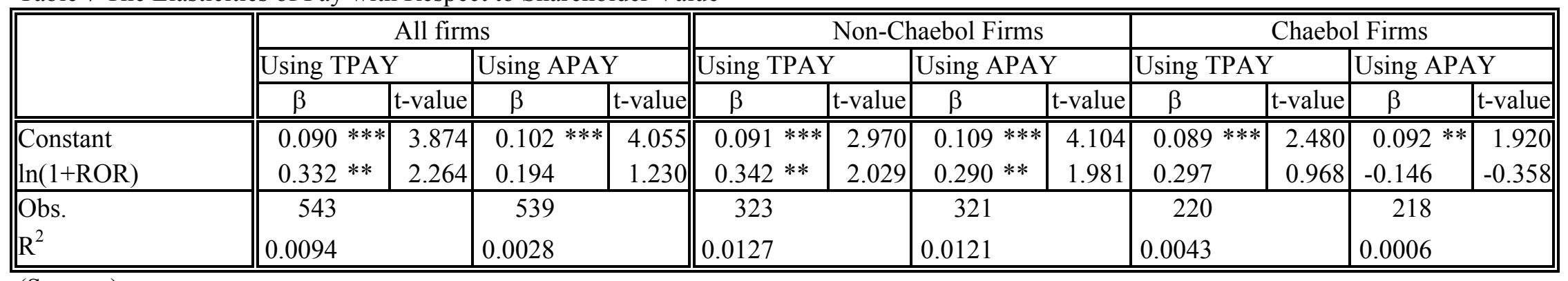

(Sources)

1. Data on TPAY (Total Annual Cash Compensation of All Directors) and APAY (Total Annual Cash Compensation of All Directors Per Director) are from Annual report of each company (can be accessed from Korea Stock Exchange or

Financial Supervisory Service websites: http://kind.kse.or.kr/ and http://dart.fss.or.kr/)

2. Data on Stock Returns are from Korea Securities Research Institute (KSRI).

3. We classified all firms into Chaebol and Non-Chaebol firms by going over the KFTC press releases on large business groups.

(Notes)

1. The data are based on 251 firms that were included in KOSPI200 for at least two consecutive years over the sample period of 1998 to 2001 .

2. Variable definitions:

TPAY=Total annual cash compensation of all directors in 1995-constant won;

APAY=Total annual cash compensation of all directors per director in 1995-constant won;

$\mathrm{ROR}==$ Stock Returns. 